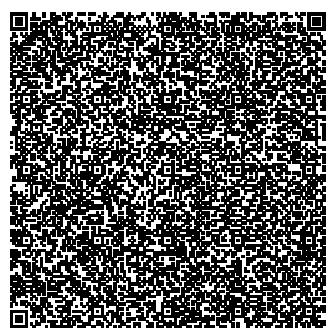

\title{
The Effect of Information Technology on Organizational Performance: The
} Mediating Role of Quality Management Capabilities

Laith Walid Fatafta, MBA, Department of Business Management, School of Business, The University of Jordan, Amman, Jordan, ebawayah@hotmail.com

Bader Obeidat, Department of Business Management, School of Business, The University of Jordan, Amman, Jordan, b.obeidat@ju.edu.jo http://orcid.org/0000-0002-1335-4057

Ashraf Bany Mohammed, School of Business, The University of Jordan, Amman, Jordan;a.bany@ju.edu.jo

Raed Kareem Kanaan, Amman Arab University, Amman, Jordan, rk@aau.edu.jo

\section{Abstract:}

This study aims to investigate the effect of information technology on organizational performance in Jordanian pharmaceutical companies, and whether quality management capabilities mediate the effect of information technology on organizational performance. Adopting a quantitative research design, data was collected by means of a questionnaire-based survey of employees in Jordanian pharmaceutical companies. Based on 338 usable responses, the results revealed a significant effect of information technology and one of its dimensions (enterprise resource planning) on organizational performance. The Other dimension (electronic data interchange) did not contribute to quality management capabilities. Additionally, the results showed that information technology has a significant effect on quality management capabilities, and that quality management capabilities in turn affect organizational performance. The findings confirm that quality management capabilities partially mediate the effect of information technology on organizational performance. The study emphases that Jordanian pharmaceutical companies should improve and promote information technology methods and practices in order to improve their performance. Pharmaceutical companies should also consider improving their quality management capabilities, as this plays a significant role in enhancing and supporting the effect of information technology on organizational performance. This study states many recommendations for future researches, but the most important ones are to apply such a research on other sectors.

Keywords: Information technology, quality management capabilities, organizational performance, Jordanian pharmaceutical companies

Citation:

Fatafta, Laith Walid ; Obeidat, Bader; Mohammed, Ashraf Bany; Kanaan, Raed Kareem (2019); The Effect of Information Technology on Organizational Performance: The Mediating Role of Quality Management Capabilities; Journal of Social Sciences (COES\&RJ-JSS), Vol.8, No.3, pp:456-480; https://doi.org/10.25255/jss.2019.8.3.456.480.

This work is licensed under a Creative Commons Attribution 4.0 International License. 


\section{Introduction}

Nowadays, the business market is influenced by the environmental uncertainty that might have negative consequences on organizations. Therefore, organizations are seeking to respond to these changes by enhancing their capabilities in order to survive and meet the customer needs (Jahanshahi, 2016; Khwaldeh et al., 2017; Kanaan and Masa'deh, 2018). This can be done by applying new technologies that are characterized by flexibility and responsiveness, which in turn lead to competitive advantage (Lai et al., 2006; Altamony et al., 2012; Karajeh and Maqableh, 2014). Indeed, firms should pay more attention to developing their information technology to be considered as one of their main capabilities. Other words, information technology consists of electronic data interchange (EDI) and enterprise resource planning (ERP) is seen as a main factor for enhancing organizational performance (Winniford et al., 2009; Yassien and Mufleh, 2017).

The concept of information technology is an important component along with quality management capabilities in order to catch the success of organizational performance. Basically, it requires the organization to get a high performance on different levels such as the electronic data interchange and enterprise resource planning system with the mediator effect of quality management capabilities (customer and supplier relations and product design). Majority of studies concentrated generally on the importance of adopting information technology and quality management capabilities within the organization (Lai et al., 2006). This study seeks to analyze theoretically and empirically how the information technology and quality management capabilities influence the non-financial outcomes of an organization. Furthermore, it will represent one of the studies that focus on the developing countries (Jordan) regarding the effect of the information technology with mediator effect through quality management capabilities on organizational performance.

Scholars have found that information technology positively influences organizational performance, in which the presence of EDI and ERP leads to more reliable and responsive behavior that boosts firm performance. Moreover, the relationship between information technology and organizational performance has been extensively studied. Researchers have always looked at organizational performance as the degree to which an organization achieves its market and financial goals (Chavez et al., 2017). Therefore, organizational performance has become a topic of interest for all organizations, profit or non-profit, and managers are interested in figuring out which factors influence organizational performance in order to take appropriate steps to initiate them (Alenezi et al., 2015, 2017; Tarhini et al., 2015, 2017a, b).

Quality management refers to various management measures and plans that are implemented to improve quality, reduce costs, and promote productivity, as well as to enhance corporate performance and competitiveness (Li et al., 2018). Rodríguez-Escobar and González-Benito (2015) stated that quality management capabilities (QMC) processes may result in improving operational performance measures such as improving flexibility, faster delivery and improving customer and supplier relationship. In fact, QMC is continuously growing and expanding. Thus, the research will use $\mathrm{QMC}$ as a mediator to explain the relationship between information technology and organizational performance (Wai et al., 2011).

In today's business environment, the global economy is influenced by the ambiguous shifts that would badly affect the organizations. These shifts put on the shoulders of organizations more responsibility to survive while improving their performance (Mjema et al., 2005). Indeed, this requires generating abilities that keep pace with rapid changes especially with the existence of knowledge revolution. Dewhurst et al., (2003) found that developing information technology leads to an increase in the firm's performance specifically in the Arab region including Jordan. This study is in one of few that investigates the mediating role of quality 
management capabilities on the effect of information technology and organizational performance in pharmaceutical companies in Jordan.

The pharmaceutical companies in Jordan face challenges such as the higher level of competition, growing and changing customer demands, transfer of inaccurate information, which force these companies to apply technologies in order to keep up with these changes quickly and help them to raise the level of quality in all practices to achieve better performance. As for quality management capabilities and information technology is considered as key player that leads to better quality practices (Sanchez-Rodriguez and Martinez-Lorente, 2011). Further, quality practices are one of the main organizational philosophies toward improving firm performance (Power, 2014).

Generally speaking, Jordan is recognized for its strong health care services due to the continuous support of the Jordanian government to the health care sector. Pharmaceutical industry is the second largest exporting industry in Jordan, representing $9.1 \%$ of the country's total export until 2013 which included $84 \%$ human medication. The total exports are $\$ 8.385$ billion (2014 est.), accordingly, contributing strongly to reducing the deficit in Jordan's trade balance. The Jordanian pharmaceutical industry has grown impressively over the five decades and as of 2016, the number of pharmaceutical companies in Jordan reached to 14 companies. The high quality, splendid reputation and affordable price of the Jordanian pharmaceutical products led this industry into exporting about $75 \%$ of their production to 70 Arab and foreign countries, and the largest part is exported to Arab countries. In addition, health service market in Jordan is growing with opportunities for investments in medical service and devices, and Jordanian pharmaceuticals are registered over many countries around the world. The pharmaceutical industry in Jordan is based on strong and adequate human resources, knowing that holders of post-secondary educational degrees (Diploma, BSc, MSc, and PhD) are representing more than $67 \%$ of the industry's total employees. It employs around 5,414 people, of whom $37 \%$ are females, which indicates it's leading the way for female contribution to economy. Finally, keeping a competitive position of pharmaceutical companies is significantly important to Jordan's competitive position in this industry, within the region or internationally.

Accordingly, this study will attempt to address the following questions:

- What is the effect of information technology on organizational performance in pharmaceutical companies in Jordan?

- What is the effect of information technology on quality management capabilities in pharmaceutical companies in Jordan?

- What is the effect of quality management capabilities on organizational performance in pharmaceutical companies in Jordan?

- Do the quality management capabilities mediate the effect of information technology on organizational performance in pharmaceutical companies in Jordan?

\section{Research Theoretical Model}

Figure (1) presents the research model which clarifies the effect between study variables the mediating role of quality management capabilities (with the two dimensions customer and supplier relations, and product design) on the effect of information technology (with the two dimensions electronic data interchange, and enterprise resource planning) and organizational performance. 


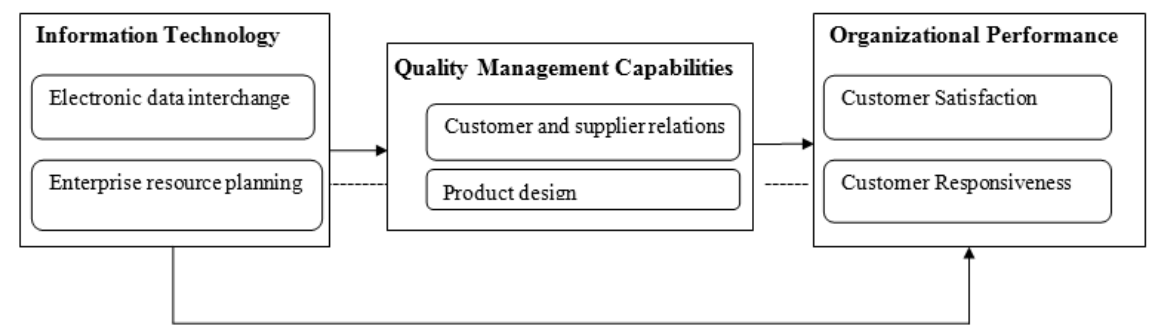

Figure 1. Research Theoretical Framework: This model developed by the researchers based on studies of Sanchez-Rodriguez and Martinez-Lorente (2011), Rodríguez-Escobar and GonzálezBenito (2015), Mandal (2015).

\subsection{Research Hypotheses}

This study has four main hypotheses to examine the mediating role of quality management capabilities on the effect of information technology on organizational performance are: First Main Hypothesis:

Ho1: There is no effect (at the level $\alpha<=0.05$ ) of information technology on organizational performance.

Subhypotheses derived from the first main hypothesis:

Ho.1: There is no effect (at the level $\alpha<=0.05$ ) of electronic data interchange on organizational performance.

Ho.2: There is no effect (at the level $\alpha<=0.05$ ) of enterprise resource planning system on organizational performance.

Second main hypothesis:

Ho2: There is no effect (at the level $\alpha<=0.05$ ) of information technology on quality management capabilities.

SubHypotheses Derived from the Second Main Hypothesis:

Ho.2.1: There is no effect (at the level $\alpha<=0.05$ ) of electronic data interchange on quality management capabilities.

Ho.2.2: There is no effect (at the level $\alpha<=0.05$ ) of enterprise resource planning on quality management capabilities.

Third Main Hypothesis:

Ho3: There is no effect (at the level $\alpha<=0.05$ ) of quality management capabilities on

organizational performance.

Sub Hypotheses Derived from the Third Main Hypothesis:

Ho3.1: There is no effect (at the level $\alpha<=0.05$ ) of customer and supplier relations on organizational performance.

Ho3.2: There is no effect (at the level $\alpha<=0.05$ ) of product design on organizational performance.

Fourth Main Hypothesis:

Ho4: There is no mediating role of quality management capabilities on the effect of information technology on organizational performance.

\subsection{Operational Definition}

The following sections elaborate operational definitions for the study variables and their dimensions based on previous studies of information technology, quality management capabilities and organizational performance. 
Information Technology: Hajli et al. (2015) defined IT as the set of computer software, computer hardware, and communications equipment, the way in which it is currently reflected in the organizational performance. This variable will be measured using questions (1-9) in the questionnaire.

Electronic Data Interchange: it is defined as a type of electronic commerce (EC) that allows organizations to exchange information and business documents electronically in a structured by machine-readable format (Kelsey, 2015). This dimension will be measured using questions (1-4) in the questionnaire.

Enterprise Resource Planning: it is useful tool for companies to build a strong information systems infrastructure and to enable the management to undertake better decision making based on accurate and on-time information that help to improve product and process quality and customer responsiveness and also enhance information sharing and information quality among different departments inside the organizations (Shatat and Udin, 2012). This dimension will be measured using questions (5-9) in the questionnaire.

Quality Management Capabilities: QMC is defined as the ability of an organization to identify, utilize, and absorption both internal and external resources/information to facilitate the completion of quality management activities in order to develop products and services that satisfy or exceed customer expectations (Sanchez-Rodriguez and Martinez-Lorente, 2011). This variable will be measured using questions (10-20) in the questionnaire.

Customer and Supplier Relations: it is defined as the communicator's task to create awareness, build accurate information by promoting quality and other features, and convince and encourage customer to make the purchase decision (Oly Ndubisi et al., 2007). This dimension will be measured using questions (10-16) in the questionnaire.

Product Design: can be defined as creating a new product to be sold to the organization's customers. Such abstract concept, it is essentially the efficient and effective generation and development ideas through process that lead to new products (Xia et al., 2015). This dimension will be measured using questions (17-20) in the questionnaire.

Organizational Performance: it can be defined as the degree to which an organization is able to meet its own needs and the needs of its stakeholders in order to survive (Middleton, 2003). This variable will be measured using questions (21-31) in the questionnaire.

Customer Satisfaction: it is defined as customer feelings of pleasure or disappointment that conclusion from comparing a product's perceived outcome with his/her expectations (Kasiri et al., 2017). This dimension will be measured using questions (21-25) in the questionnaire.

Customer Responsiveness: it is defined as the action taken in response to market intelligence concerning individual needs of target customers. For the industrial firm, customer responsiveness includes value-adding activities such as building relationships with customers and solving customers' problems (Pehrsson, 2014). This dimension will be measured using questions (26-31) in the questionnaire.

\subsection{Population and Unit of Analysis}

This research was conducted in the city of Amman (the capital of the Hashemite Kingdom of Jordan). The population of this research was all employees who work at the fourteen pharmaceutical companies that operate in Amman. It was found that 5,414 employees work in such companies. 
Journal of Social Sciences (COES\&RJ-JSS), 8(3), pp.456-480

Table 1. The Jordanian Association of Manufacturers of Pharmaceuticals and Medical Appliances

\begin{tabular}{|l|l|l|l|}
\hline $\begin{array}{l}\text { N } \\
\text { o. }\end{array}$ & Company Name & $\begin{array}{l}\text { Established } \\
\text { Year }\end{array}$ & $\begin{array}{l}\text { Number of } \\
\text { Employees }\end{array}$ \\
\hline 1 & The Arab Pharm.Mfg. Co. Ltd. & 1962 & 856 \\
\hline 2 & Dar Al-Dawa Develop \& Invst. Co. & 1957 & 786 \\
\hline 3 & Hikma Pharmaceuticals & 1977 & 1,004 \\
\hline 4 & The Jordanian. Mfg. Co. & 1978 & 478 \\
\hline 5 & Arab Center for Pharm. \& Chem. & 1983 & 260 \\
\hline 6 & United Pharmaceuticals & 1989 & 382 \\
\hline 7 & Hayat Pharm. Ind. Co. Ltd. & 1993 & 166 \\
\hline 8 & RAM Pharma & 1992 & 189 \\
\hline 9 & MID Pharma & 1993 & 312 \\
\hline 10 & Pharma International & 1994 & 460 \\
\hline 11 & Jordan Sweden Medical \&Strz. & 1996 & 175 \\
\hline 12 & TQ PHARMA & 2007 & 86 \\
\hline 13 & Jordan River Pharm. Ind. & 1999 & 80 \\
\hline 14 & Amman Pharmaceutical Industries & 1989 & 250 \\
\hline Total number of employees & & 5,414 \\
\hline
\end{tabular}

Jordan's pharmaceutical organizations are controlled by the Ministry of Health (MoH), managed by the Jordanian Food and Drug Association (JFDA) and governed by local regulations and standards that follow international standards. These organizations import raw materials, process them, and develop pharmaceutical ones for international marketplaces such as the United States, India, and China. Pharmaceutical organizations in Jordan do not produce any drugs of their own, but $40 \%$ of their production hinges on the franchising rights of foreign organizations and the other $60 \%$ hinges on licensing (Al-Shaikh et al., 2011). The convenience sampling technique was used in collecting the data of this research with a total number of minimum three hundred and seventy employees (Sekaran and Bogei, 2016). Four hundred questionnaires were distributed by the researchers to respondents (all employees), of which the researchers received back three hundred and sixty-four. Three hundred and thirty-eight questionnaires were approved, while twenty-six questionnaires were rejected for being incomplete. This study deals with each pharmaceutical company as one unit. The sample covers all levels of employees in the company.

\subsection{Data Collection and Instrument}

This research uses a primary data which was gathered through a questionnaire. The questionnaire is developed based on the literature as secondary data (publications, Journals) where the University of Jordan provides accredited resources on its website (ezlibarary.ju.edu.jo). The type of data collection is cross-sectional in which the data is collected only once. Previous literatures were used to induct the variables that were used to measure the research variables, the electronic data interchange items were adopted from Bhatt (2001); Tan, Kannan, Hsu, and Leong (2010), and Enterprise resource planning items were adopted from De Toni, Fornasier, and Nonino (2015), while the customer and supplier relations items were adopted from Tseng and Wu (2014); Narayanan, Narasimhan, and Schoenherr (2015), and product design items were adopts from Lakhal, Pasin, and Limam 
The Effect of Information Technology on Organizational Performance:....

(2006); Tseng and Wu (2014), customer satisfaction were adopted from Ang, Davies, and Finlay (2000); Lai, Zhao, and Wang (2006), and customer responsiveness were adopted from Pehrsson (2014); and Mandal (2015).

Table 2. References for the Study Variables

\begin{tabular}{|l|l|}
\hline \multicolumn{2}{|c|}{ Dimensions } \\
\hline \multicolumn{2}{|c|}{ Information Technology } \\
\hline Electronic data interchange & (Bhatt, 2001; Tan et al., 2010) \\
\hline Enterprise resource planning & (De Toni et al., 2015) \\
\hline Quality management capabilities \\
\hline Customer and supplier relations & (Tseng and Wu, 2014; Narayanan et al., 2015) \\
\hline Product design & (Lakhal et al., 2006; Tseng and Wu, 2014) \\
\hline Organizational performance & \\
\hline Customer Satisfaction & (Ang et al., 2000; Lai et al., 2006) \\
\hline Customer responsiveness & (Pehrsson, 2014; Mandal, 2015) \\
\hline
\end{tabular}

The questionnaire includes items which were developed from literature in the same field and interests. Accordingly, all scales were translated into Arabic to avoid any misunderstanding. The quality of the translation process was deeply reviewed by academic experts to ensure that all scales are clear and understandable. Finally, the questionnaire was reviewed by four academic and then modified upon their recommendations. All items are rated on a five-point Likert scale as follows: Strongly Disagree (1) - disagree (2) -neutral (3) - agree (4) - strongly agree (5) (Sekaran and Bougi, 2016). The primary data was collected by using a questionnairebased survey. The questionnaire includes two main parts as follows:

The first part of the questionnaire is regarding to demographic variables which are categorized in five main questions explained as follows:

Table 3. Demographic Items

\begin{tabular}{|l|l|}
\hline Item1 & Gender of the individual respondent \\
\hline Item2 & Age of the individual respondent \\
\hline Item3 & Respondent educational level \\
\hline Item 4 & Years of work experience for each participant \\
\hline Item 5 & Job position that each participant occupies \\
\hline
\end{tabular}

The second part is related to the main variables of the study which are: (1) information technology (electronic data interchange and enterprise resource planning) as independent variable, (2) quality management capabilities (customer and supplier relations and product design) as mediating variable, (3) organizational performance (customer satisfaction and customer responsiveness) as dependent variable. See table (4) for more explanation:

Table 4. Main Variables Items

\begin{tabular}{|l|l|l|}
\hline The variable & $\begin{array}{l}\text { Number of items used to } \\
\text { measure the variable }\end{array}$ & $\begin{array}{l}\text { Question number } \\
\text { related to each } \\
\text { variable }\end{array}$ \\
\hline Independent Variables & & \\
\hline
\end{tabular}


Journal of Social Sciences (COES\&RJ-JSS), 8(3), pp.456-480

\begin{tabular}{|l|l|l|}
\hline Information Technology & 9 items & $1-9$ \\
\hline Electronic data interchange & 4 items & $1-4$ \\
\hline Enterprise resource planning & 5 items & $5-9$ \\
\hline Mediating Variable & & \\
\hline Quality management capabilities & 11 items & $10-20$ \\
\hline Customer and supplier relations & 7 items & $10-16$ \\
\hline Product design & 4 items & $17-20$ \\
\hline Dependent Variables & & $21-31$ \\
\hline Organizational performance & 11 items & $21-25$ \\
\hline Customer satisfaction & 5 items & $26-31$ \\
\hline Customer responsiveness & 6 items & \\
\hline
\end{tabular}

\subsection{Data Analysis Techniques}

This study used different statistical techniques to analyze the data, after the data were received, verified, entered and coded into SPSS version 19, they were analyzed using the following data analysis techniques: Firstly, descriptive statistics including measures of the mean, standard deviation, percentages and frequency were used to describe and summarize the characteristics of members included in the sample of the study. Secondly, co-relational analysis was performed to determine the relationship between information technology variables and organizational performance variables as mediated by quality management capabilities variables. Finally, inferential statistics using multiple regressions were used to test the research hypotheses.

\subsection{Validity and Reliability}

After the operationalization and definition of dimensions and items of variables, it is very important to ensure that the instrument the researchers used to measure the concepts is measuring the variables correctly and precisely. The researchers have to measure the goodness of the instrument to improve scientific research quality (Sekaran and Bogei, 2016). There are two ways to evaluate the quality of the questionnaire; validity and reliability. Validity means examining the performance of the instrument to see if it measures what is supposed to measure, content and construct validity types were used to test the questionnaire goodness. While reliability refers to the consistency of the variables in measuring what is intended to be measured.

\subsubsection{Content and Face Validity}

The questions and survey items were adopted from previous literature. Thus, to ensure validity in this research, the researchers conducted a pretesting questionnaire in coordination with academic experts in the same field and interests, in order to ensure that any errors in the questionnaire have been eliminated.

\subsubsection{Construct Validity (Factor Analysis)}

Construct validity refers to "how well the results obtained from the use of the measure fit the theories around which the test is designed" (Sekaran and Bougie, 2016, p. 160). It is regarded as the heart of any study, where a measure has been used as an index of a variable that cannot be directly observed. One way to examine construct validity is through the use of factor analysis (Sekaran and Bougie, 2016). Exploratory factor analysis used to check the research construct validity: information technology (electronic data interchange and enterprise resource planning), quality management capabilities (customer and supplier relations and product design), and organizational performance (customer satisfaction and customer 
responsiveness).Three assumptions were followed to conduct EFA as suggested by Hair et al. (2009): sampling adequacy (Kiaser-Meyer-Olkin measure $>0.5$ ), the eigen values for each factor should be $>1$, and a factor loading of 0.30 for each item is used as the threshold for item retention.

The results show that the Kaier-Meyer-Olkin (KMO) index which ranges from (0) to (1) is (0.845) for information technology, $(0.907)$ for quality management capabilities, and (0.904) for organizational performance which are all well above the recommended threshold suggested by Hair et al. (2009). The Bartlett's Test of Sphericity was statistically significant ( $p$ value $=0.000<0.05$ ) for all three variables indicating that the correlations are sufficiently large for factor analysis (Hair et al., 2009). Both the KMO and Bartlett's Test of Sphericity are prerequisites for the extraction of the factors and are used to test the appropriateness of the data for factor analysis (Williams et al., 2010). Moreover, a correlation matrix is introduced in the EFA process as a means of showing the relationships between variables and is investigated for correlation coefficients over (0.30). There are a number of correlations greater than $(0.30)$ exist in this study, which indicates that factor analysis, is an appropriate statistical method to be used in this research.

Table number five, shows the result of EFA of information technology items. A two-factor model emerged explaining $60.883 \%$ of the total variation. A factor number one, was labeled 'Electronic data interchange', and includes all the four items originally developed to measure it (EDI1-EDI4). Regarding factor number two, was labeled 'Enterprise resource planning' and includes all the five items originally developed to measure it (ERP1-ERP5).Table number six, shows the result of EFA of quality management capabilities items. A two-factor model emerged explaining $61.957 \%$ of the total variation. Factor number one was labeled 'supplier and customer relations' and includes all the seven items originally developed to measure it (CSR1-CSR7).Regarding factor number two, labeled as 'product design, and includes four items originally developed to measure it(PD1-PD4). Table number seven, shows the result of EFA of organizational performance items. A two-factor model emerged explaining $61.735 \%$ of the total variation. Factor number one was labeled 'customer satisfaction' and includes all the five items originally developed to measure it (CS1-CS5). Regarding factor number two, labeled as 'customer responsiveness, and includes six items originally developed to measure it(CR1-CR6).

Table 5. Exploratory Factor Analysis (EFA) Results for Information Technology Construct

\begin{tabular}{|l|l|l|l|}
\hline Questions & Your EDI capability in improving customer service. & Factor 1 & Factor 2 \\
\hline EDI1 & $\begin{array}{l}\text { Supplier EDI capability in their performance } \\
\text { improvement. }\end{array}$ & 0.539 \\
\hline EDI3 & $\begin{array}{l}\text { The firm and its main suppliers are linked through } \\
\text { information systems (EDI). }\end{array}$ & 0.824 \\
\hline EDI4 & $\begin{array}{l}\text { Through information systems, both suppliers and firm } \\
\text { can share product or service (e.g. specification, design, } \\
\text { quality, etc.) related information. }\end{array}$ & 0.884 \\
\hline ERP1 & $\begin{array}{l}\text { ERP, to my knowledge, meets its production schedules } \\
\text { such as report delivery and running scheduled. }\end{array}$ & 0.680 & 0.405 \\
\hline ERP2 & $\begin{array}{l}\text { The ERP computer systems I use are convenient and } \\
\text { easy to use. }\end{array}$ & 0.812 & \\
\hline ERP3 & $\begin{array}{l}\text { Using the ERP system enhances my effectiveness on the } \\
\text { job. }\end{array}$ & 0.858 & \\
\hline ERP4 & Using the ERP system increases my productivity. & 0.820 & \\
\hline
\end{tabular}


Journal of Social Sciences (COES\&RJ-JSS), 8(3), pp.456-480

\begin{tabular}{|l|l|l|l|}
\hline ERP5 & $\begin{array}{l}\text { My interaction with the ERP system is clear and } \\
\text { understandable. }\end{array}$ & 0.840 & \\
\hline
\end{tabular}

Table 6. Exploratory Factor Analysis (EFA) Results for Quality Management Capabilities Construct

\begin{tabular}{|c|c|c|c|}
\hline \multicolumn{2}{|c|}{ Questions } & \multirow{2}{*}{$\begin{array}{l}\text { Factor } 1 \\
0.615\end{array}$} & \multirow[t]{2}{*}{ Factor 2} \\
\hline CSR1 & $\begin{array}{l}\text { The suppliers are concerned about our success and } \\
\text { development. }\end{array}$ & & \\
\hline CSR2 & $\begin{array}{l}\text { Information provided by the supplier was reliable and } \\
\text { accurate. }\end{array}$ & 0.689 & \\
\hline CSR3 & $\begin{array}{l}\text { There was a high degree of cooperation in the } \\
\text { engagement with supplier. }\end{array}$ & 0.475 & \\
\hline CSR4 & $\begin{array}{l}\text { Our company's products have fulfilled the customers } \\
\text { demand. }\end{array}$ & 0.572 & \\
\hline CSR5 & $\begin{array}{l}\text { Our company can fulfil customer's order (or purchase } \\
\text { procedure) quickly. }\end{array}$ & 0.462 & \\
\hline CSR6 & $\begin{array}{l}\text { Our company's staffs are equipped with excellent } \\
\text { communication ability with customer. }\end{array}$ & 0.890 & \\
\hline CSR7 & $\begin{array}{l}\text { Our company provides customers with good after-sales } \\
\text { service. }\end{array}$ & 0.682 & \\
\hline PD1 & Our company's products possess attractive designs. & & 0.683 \\
\hline PD3 & $\begin{array}{l}\text { Our company's products have fulfilled the customer's } \\
\text { demand. }\end{array}$ & & 0.719 \\
\hline PD3 & $\begin{array}{l}\text { Customer is integrated in the product development } \\
\text { process. }\end{array}$ & & 0.853 \\
\hline PD4 & $\begin{array}{l}\text { Company carries out market studies to determine its } \\
\text { customers' needs and wants. }\end{array}$ & & 0.794 \\
\hline
\end{tabular}

Table 7. Exploratory Factor Analysis (EFA) Results for Organizational Performance Construct

\begin{tabular}{|c|c|c|c|}
\hline \multicolumn{2}{|c|}{ Questions } & Factor 1 & Factor 2 \\
\hline CS1 & Identify customers' needs. & 0.806 & \\
\hline CS2 & Assess customers' needs. & 0.594 & \\
\hline CS3 & Measure customers' satisfaction. & 0.910 & \\
\hline CS4 & $\begin{array}{l}\text { Improve communication between your company and } \\
\text { customers. }\end{array}$ & 0.836 & \\
\hline CS5 & $\begin{array}{l}\text { Providing requested and customized services to } \\
\text { customers. }\end{array}$ & 0.822 & \\
\hline CR1 & $\begin{array}{l}\text { We pay attention to finding solutions to customers' } \\
\text { problems. }\end{array}$ & & 0.802 \\
\hline CR2 & We pay attention to relationships with customers. & & 0.435 \\
\hline CR3 & We pay attention to customization of the offering. & & 0.656 \\
\hline CR4 & $\begin{array}{l}\text { Your operation system can reconfigure capacity and } \\
\text { processes to address demand changes. }\end{array}$ & & 0.914 \\
\hline CR5 & $\begin{array}{l}\text { Your suppliers can effectively expedite your } \\
\text { emergency orders. }\end{array}$ & & 0.640 \\
\hline CR6 & $\begin{array}{l}\text { Your suppliers can change product volume and mix in } \\
\text { a relatively short time. }\end{array}$ & & 0.669 \\
\hline
\end{tabular}




\subsection{Reliability}

Reliability is defined as a degree to which a test consistently measures whatsoever (Gay and Airasian, 2000, p. 169). Therefore, the reliability test is used to determine the internal consistency of the construct items. Cronbach's coefficient Alpha was used to assess the reliability of the scales (Cronbach, 1951). As a rule of thumb, Cronbach's $\alpha \geq 0.60$ is acceptable (Nunnally, 1978; Hair et al., 2009). As shown in Table 8, the results expose that all alpha values are above 0.60 indicating that items are totally consistent with the variables to be measured.

Table 8. Cronbach's Alpha Coefficients

\begin{tabular}{|c|c|c|}
\hline Construct & Number of Items & Cronbach's Alpha \\
\hline \multicolumn{3}{|l|}{ Information technology } \\
\hline Electronic data interchange & 4 & 0.702 \\
\hline Enterprise resource planning & 5 & 0.865 \\
\hline Information technology & 9 & 0.855 \\
\hline \multicolumn{3}{|l|}{ Quality management capabilities } \\
\hline - Customer and supplier relations & 7 & 0.887 \\
\hline - Product design & 4 & 0.792 \\
\hline Quality management capabilities & 11 & 0.916 \\
\hline \multicolumn{3}{|l|}{ Organizational performance } \\
\hline - Customer satisfaction & 5 & 0.867 \\
\hline - Customer responsiveness & 6 & 0.786 \\
\hline Organizational performance & 11 & 0.882 \\
\hline
\end{tabular}

\section{Data Analysis}

This study aims to investigating the effect of information technology (electronic data interchange and enterprise resource planning) on organizational performance (customer satisfaction and customer responsiveness) through of quality management capabilities (customer and supplier relations and product design). Consequently, to obtain the main purpose of this study, this research shows the analysis of the primary data using the statistical package for social sciences (SPSS) version 22.

\subsubsection{Response Rate}

As shown before, four hundred questionnaires were distributed by the researchers to the respondents, while the researchers received three hundred and sixty-four questionnaires. Three hundred and thirty-eight questionnaires were approved, while twenty-six questionnaires were rejected because the respondents did not answer all sections of the questionnaire. Accordingly, the response percentage was $84.5 \%$.

\subsection{1.2. Demographic Characteristics of Participating Respondents'}

This section display the demographic characteristics of respondents including age, gender, education, experience and position. For more clarification, see Table 9 below.

Table 9. Demographic Characteristics of the Respondents

\begin{tabular}{|c|c|c|}
\hline & Frequency & Percent \\
\hline \multicolumn{3}{|l|}{ Gender } \\
\hline Male & 222 & 65.7 \\
\hline Female & 116 & 34.3 \\
\hline Total & 338 & 100.0 \\
\hline \multicolumn{3}{|l|}{ Age } \\
\hline Less than 25 & 139 & 41.1 \\
\hline
\end{tabular}




\begin{tabular}{|c|c|c|}
\hline 25 -less than 30 & 72 & 21.3 \\
\hline 30-less than 35 & 75 & 22.2 \\
\hline 35 years and above & 52 & 15.4 \\
\hline \multicolumn{3}{|l|}{ Education } \\
\hline Two-yeas Diploma & 31 & 9.2 \\
\hline Bachelor Degree & 239 & 70.7 \\
\hline Higher Diploma & 34 & 10 \\
\hline Master's Degree & 29 & 8.6 \\
\hline PhD & 5 & 1.5 \\
\hline \multicolumn{3}{|l|}{ Experience } \\
\hline Less than 3 years & 104 & 30.8 \\
\hline 3-less than 6 years & 95 & 28.1 \\
\hline 6 -less than 9 years & 85 & 25.1 \\
\hline 9 years and above & 54 & 16 \\
\hline \multicolumn{3}{|l|}{ Position } \\
\hline Top management level (CEO, GM, Assistant GM) & 8 & 2.4 \\
\hline $\begin{array}{l}\text { Middle management level (Division Director, Head of Main } \\
\text { Division) }\end{array}$ & 45 & 13.3 \\
\hline Supervisor level (Supervisor, Team Leader) & 78 & 23.1 \\
\hline Non-Administrative level & 207 & 61.2 \\
\hline
\end{tabular}

\subsection{DESCRIPTIVE STATISTICS}

This section presents descriptive statistics of the study variables. Descriptive statistics provide preliminary view concerning the data used in the subsequent analysis (Tabachnick and Fidell, 2007). To identify the principal trends in the research data, means and standard deviations of study, constructs were computed as reported in table 10 .

Some researchers classifies the variables according to three ranges: high (3.67-5.00), medium $(2.34-3.66)$, and low $(1.00-2.33)$

The category length was computed according to the below equation:

Category length $=$ (upper limit - lower limit) $/$ number of levels. So, the category length in this study $=(5-1) / 3=1.33$

Table 10. Descriptive Statistics for the Research Variables

\begin{tabular}{|c|l|c|c|c|}
\hline Type of variable & \multicolumn{1}{|c|}{ Variables } & Mean & $\begin{array}{c}\text { Std. } \\
\text { Deviation }\end{array}$ & Classification \\
\hline Independent Variable & $\begin{array}{l}\text { Information } \\
\text { Technology }\end{array}$ & 3.687 & 0.85 & High \\
\cline { 2 - 5 } & $\begin{array}{l}\text { Electronic Data } \\
\text { Interchange }\end{array}$ & 3.522 & 0.826 & Medium \\
\cline { 2 - 5 } & $\begin{array}{l}\text { Enterprise Resource } \\
\text { Planning }\end{array}$ & 3.852 & 0.875 & High \\
\hline Mediating Variable & $\begin{array}{l}\text { Quality Management } \\
\text { Capabilities }\end{array}$ & 4.023 & 0.871 & High \\
\cline { 2 - 5 } & $\begin{array}{l}\text { Customer and Supplier } \\
\text { Relations }\end{array}$ & 3.991 & 0.861 & High \\
\cline { 2 - 5 } & Product Design & 4.055 & 0.882 & High \\
\hline Dependent Variable & Organizational & 3.98 & 0.902 & High \\
\hline
\end{tabular}


The Effect of Information Technology on Organizational Performance:....

\begin{tabular}{|l|l|c|c|c|}
\hline & Performance & & & \\
\cline { 2 - 5 } & Customer Satisfaction & 4.202 & 0.878 & High \\
\cline { 2 - 5 } & $\begin{array}{l}\text { Customer } \\
\text { Responsiveness }\end{array}$ & 3.758 & 0.927 & High \\
\hline
\end{tabular}

The results show that the mean values of all study constructs are above the average score of 3 $(5+1 / 2=3)$. Generally, all the mean values reflect a positive trend indicating that the surveyed pharmaceuticals companies in Jordan have a positive attitude towards these measures.

\subsection{HYPOTHESES TESTING}

\subsubsection{MULTICOLLINEARITY}

Multicollinearity refers to the way that two or more independent variables are described as highly correlated. This study uses the tolerance value and the variance inflation factor (VIF) as measures to test Multicollinearity. According to Hair et al. (2009), the values of tolerance more than 0.10 , and for VIF less than 10 might be acceptable; however, they point out the fact that much lower values of VIF may indicate the existence of multicollinearity. The cutoff VIF value of 2.5 proposed by Allison (1999) is widely adopted by many leading journals; therefore, it is also adopted by this study. The VIF values for the independent variables are less than 2.5 as shown in table (11) which indicates that multicollinearity is not a potential problem in the regression models.

Table 11. Collinearity Statistics and VIF

\begin{tabular}{|l|c|c|}
\hline \multicolumn{1}{|c|}{ Variables } & \multicolumn{2}{c|}{ Collinearity Statistics } \\
\cline { 2 - 3 } & Tolerance & (VIF) \\
\hline Electronic data interchange & 0.773 & 1.293 \\
\hline Enterprise resource planning & 0.773 & 1.293 \\
\hline
\end{tabular}

\subsubsection{REGRESSION ANALYSIS}

1.1.1 3.3.2.1. Testing the First Hypothesis (Ho1)

The first hypothesis states that there is no effect of Information Technology on Organizational Performance. The results of testing the first main hypothesis are explained in tables 12,13 as follows:

Table 12. Model Summary of the First Main Hypothesis

\begin{tabular}{|c|c|c|c|c|}
\hline Model & $\mathrm{R}$ & $\mathrm{R}$ Square & $\begin{array}{c}\text { Adjusted } \mathrm{R} \\
\text { Square }\end{array}$ & $\begin{array}{c}\text { Std. Error of } \\
\text { Estimation }\end{array}$ \\
\hline 1 & $.621^{\text {(a) }}$ & .385 & .382 & 0.560 \\
\hline
\end{tabular}

a. Predictors: (Constant), Electronic data interchange, Enterprise resource planning

b. Dependent variable: Organizational performance.

Table 13. ANOVA of the First Main Hypothesis

\begin{tabular}{|l|c|c|c|c|c|}
\hline \multicolumn{1}{|c|}{ Model } & Sum of Squares & Df & Mean Square & F & Sig. \\
\hline Regression & 65.731 & 2 & 32.866 & $\begin{array}{c}104.94 \\
6\end{array}$ & .000 \\
\hline Residual & 104.911 & 335 & .313 & & \\
\hline Total & 170.642 & 337 & & & \\
\hline
\end{tabular}




\section{Journal of Social Sciences (COES\&RJ-JSS), 8(3), pp.456-480}

a. Predictors: (Constant), Electronic data interchange, Enterprise resource planning

b. Dependent variable: Organizational performance.

The multiple correlation coefficient $\mathrm{R}=0.621$ shows that there is a strong positive correlation between information technology (electronic data interchange and enterprise resource planning) and organizational performance. It means that the dependent and independent variables turn in the same direction. The $R$ value is a standard of how well the model port ends the observed data. The value of $R^{2}=0.385$ shows that information technology can account for $38.5 \%$ of the variation of organizational Performance. In addition, it means that the higher the information technology is, the better the organizational Performance is to be expected.

The adjusted $R^{2}=0.382$ shows the generalizability of the model. It allows generalizing the results taken from the sample over the whole population. It is observed that the value of adjusted $R^{2}$ is very close to the value of $R^{2}$. If the adjusted $R^{2}$ is excluded from $R^{2}(0.385-0.382)$ then the result will be (0.003).This amount of decrease $(0.003)$ means that there will be $0.3 \%$ lower variance in the outcome, if the whole population takes part in the study and that the model has been suited.

The second part of the output is the analysis of variance (ANOVA) which is used to statistically test the first main null hypotheses. It is concluded that the F-ratio for the data is 104.946which is significant at $(p<0.05)$ (Alpha in this case equals sig=.000). This result shows that there is less than a $0.05 \%$ chance that an F-ratio of this value would only happen by chance. In conclusion, there is an effect of Information Technology on Organizational Performance, and thus, we reject the null hypotheses.

The second part of multiple regression analysis is about testing the effect of the dependent variable in the model of each predictor. Standardized Beta coefficients $\beta$ and $\alpha$ significance levels were used to test the effect of information technology (electronic data interchange and enterprise resource planning) on organizational performance.

Table 14. Coefficient of Predictors of the First Main Hypothesis

\begin{tabular}{|l|c|c|c|c|c|}
\hline \multirow{2}{*}{ Model } & \multicolumn{2}{|c|}{$\begin{array}{c}\text { Unstandardized } \\
\text { Coefficients }\end{array}$} & $\begin{array}{c}\text { Standardized } \\
\text { Coefficients }\end{array}$ & \multirow{2}{*}{ Sig. } & \\
\cline { 2 - 5 } & $\mathrm{B}$ & $\begin{array}{c}\text { Std. } \\
\text { Error }\end{array}$ & Beta & \\
\hline (Constant) & 1.524 & .187 & & 8.156 & .000 \\
\hline $\begin{array}{l}\text { Electronic data } \\
\text { interchange }\end{array}$ & .149 & .052 & .140 & 2.881 & .004 \\
\hline $\begin{array}{l}\text { Enterprise resource } \\
\text { planning }\end{array}$ & .490 & .044 & .541 & 11.116 & .000 \\
\hline
\end{tabular}

Dependent Variable: Organizational performance

The standardized beta coefficient $(\beta)$ shows the individual support of (independent variable) predictors to the model, if other predictors are held fixed. The above table number 14 shows the standardized coefficients for each information technology dimensions. First dimension is electronic data interchange, the $\beta$ coefficient was statistically significant where the significant level is 0.004 , provided $(p>(0.05))$, while the other dimension which is enterprise resource planning was significant too due to the significance level of $p=(.000)$ which is less than $(0.05)$ and this dimension affects strongly on organizational performance where $\beta=0.490$. 
The Effect of Information Technology on Organizational Performance:....

Regarding the testing of the first main hypothesis, the results of the first sub-hypotheses are described in the table15 below.

Table 15. Results of Testing the Sub-Hypotheses of the First Main Hypothesis

\begin{tabular}{|l|c|}
\hline \multicolumn{1}{|c|}{ Null Sub-Hypotheses } & Result \\
\hline $\begin{array}{l}\text { H01.1: There is no effect of electronic data interchange on organizational } \\
\text { performance }\end{array}$ & Rejected \\
\hline $\begin{array}{l}\text { H01.2: There is no effect of enterprise resource planning system on } \\
\text { organizational performance }\end{array}$ & Rejected \\
\hline
\end{tabular}

The table above shows that the first sub-hypotheses was rejected due to the significance level $(p<0.05)$ which indicates that there is an effect of electronic data interchange on organizational performance, likewise the second sub-hypotheses indicates that there is an effect of enterprise resource planning system on organizational performance due to $(p<0.05)$.

\subsection{2. Testing the Second Hypothesis (Ho2)}

The second hypothesis states that there is no effect of information technology on quality management capabilities.

The results of testing this main hypothesis are demonstrated in tables16, 17 as follows:

Table 16. Model Summary of the Second Main Hypothesis

\begin{tabular}{|c|c|c|c|c|}
\hline Model & $\mathrm{R}$ & R Square & $\begin{array}{c}\text { Adjusted R } \\
\text { Square }\end{array}$ & $\begin{array}{c}\text { Std. Error of } \\
\text { Estimation }\end{array}$ \\
\hline 1 & $.607^{(\mathrm{a})}$ & .369 & .365 & 0.572 \\
\hline
\end{tabular}

a. Predictors: (Constant), Electronic data interchange, Enterprise resource planning

b. Dependent variable: Quality management capabilities

Table 17. ANOVA of the Second Main Hypothesis

\begin{tabular}{|l|c|c|c|c|c|}
\hline \multicolumn{1}{|c|}{ Model } & $\begin{array}{c}\text { Sum of } \\
\text { Squares }\end{array}$ & Df & Mean Square & $\mathrm{F}$ & Sig. \\
\hline Regression & 64.046 & 2 & 32.023 & $\begin{array}{c}97.94 \\
5\end{array}$ & .000 \\
\hline Residual & 109.528 & 335 & .327 & & \\
\hline Total & 173.574 & 337 & & & \\
\hline
\end{tabular}

a. Predictors: (Constant), Electronic data interchange, Enterprise resource planning

b. Dependent variable: Quality management capabilities

The multiple correlation coefficient $\mathrm{R}=0.607$ shows that there is a strong positive correlation between information technology (electronic data interchange and enterprise resource planning) and quality management capabilities (customer and supplier relations and product design). It means that the dependent and independent variables turn in the same direction. The $R$ value is a standard of how well the model portends the observed data.

The value of $R^{2}=0.369$ shows that the information technology can account for $36.9 \%$ of the variation of quality management capabilities. In addition, it means that the higher the information technology is, the better the applicability of quality management capabilities is to be expected. The adjusted $R^{2}=0.365$ is interested in the generalizability of the model. It allows for generalizing the results taken from this sample over the whole population. It is observed that the value of adjusted $R^{2}$ is very close to the value of $R^{2}$. If the adjusted $R^{2}$ is excluded from $R^{2}(0.369-0.365)$ then the result will be $(0.004)$. This amount of decrease $(0.004)$ means that 
there will be $0.4 \%$ lower variance in the outcome if the whole population takes part in the study and that the model has been suited.

The second part of the output is the analysis of variance (ANOVA) which is used to statistically test the first main null hypotheses. It is concluded that the F-ratio for the data is 97.945 which is significant at $(p<0.05)$ (Alpha in this case equals $\operatorname{sig}=.000)$. This result shows that there is less than a $0.05 \%$ chance that an F-ratio of this value would only happen by chance. In conclusion, there is an effect of Information Technology on quality management capabilities, and thus, we reject the null hypotheses.

The second part of multiple regression analysis is about testing the effect of the dependent variable in the model for each predictor. Standardized Beta coefficient $\beta$ and $\alpha$ significance levels were used to test the effect of Information Technology on Quality management capabilities.

Table 18. Coefficient of Predictors for the Second Main Hypothesis

\begin{tabular}{|l|c|c|c|c|c|}
\hline \multirow{2}{*}{ Model } & \multicolumn{2}{|c|}{$\begin{array}{c}\text { Unstandardized } \\
\text { Coefficients }\end{array}$} & $\begin{array}{c}\text { Standardized } \\
\text { Coefficients }\end{array}$ & T & \\
\cline { 2 - 5 } & $\mathrm{B}$ & Std. Error & Beta & & \\
\hline (Constant) & 1.803 & .191 & & 9.444 & .000 \\
\hline $\begin{array}{l}\text { Electronic data } \\
\text { interchange }\end{array}$ & .041 & .053 & .038 & .766 & .444 \\
\hline $\begin{array}{l}\text { Enterprise resource } \\
\text { planning }\end{array}$ & .537 & .045 & .589 & 11.926 & .000 \\
\hline
\end{tabular}

Dependent Variable: Quality management capabilities

The standardized beta coefficient $(\beta)$ shows that the individual support of (independent variable) predictors to the model, if other predictors are held fixed. The above table 18 shows the standardized coefficients for each information technology dimensions. First dimension is electronic data interchange, the $\beta$ coefficient was statistically insignificant where the significant level is 0.444 provided that $p>0.05$, while the other dimension which is enterprise resource planning was significant due to the significance level of $p=.000$ which is less than 0.05 and this dimension has a strong effect on organizational performance, where $\beta=0.537$.

Regarding the above testing of the second main hypothesis, the results of the second subhypotheses are described in the table19 below.

Table 19. Results of Testing the Sub-Hypotheses of the Second Main Hypothesis

\begin{tabular}{|l|c|}
\hline \multicolumn{1}{|c|}{ Null Sub-hypotheses } & Result \\
\hline $\begin{array}{l}\text { H02.1: There is no effect of electronic data interchange on } \\
\text { quality management capabilities. }\end{array}$ & $\begin{array}{c}\text { Accepte } \\
\mathrm{d}\end{array}$ \\
\hline $\begin{array}{l}\text { H02.2: There is no effect of enterprise resource planning on quality } \\
\text { management capabilities. }\end{array}$ & Rejected \\
\hline
\end{tabular}

The table above shows that the first sub-hypotheses was accepted due to the significance level $(p>0.05)$ which indicates that there is no effect of electronic data interchange on quality management capabilities; while the second sub-hypotheses indicates that there is an effect of enterprise resource planning on quality management capabilities due to $p<0.05$.

\subsection{Testing the Third Hypothesis ( $\mathrm{Ho3}$ )}

The third hypothesis states that there is no effect of quality management capabilities on organizational performance.

The results of testing this main hypothesis are demonstrated in tables20, 21 as follows: 
The Effect of Information Technology on Organizational Performance:....

Table 20. Model Summary of the Third Main Hypothesis

\begin{tabular}{|c|c|c|c|c|}
\hline Model & $\mathrm{R}$ & $\mathrm{R}$ Square & $\begin{array}{c}\text { Adjusted R } \\
\text { Square }\end{array}$ & $\begin{array}{c}\text { Std. Error of } \\
\text { Estimation }\end{array}$ \\
\hline 1 & $.714^{(\mathrm{a})}$ & .509 & .506 & 0.500 \\
\hline
\end{tabular}

c. Predictors: (Constant), Customer and supplier relations, Product design

d. Dependent variable: organizational performance.

Table 21. ANOVA of the Third Main Hypothesis

\begin{tabular}{|l|c|c|c|c|c|}
\hline \multicolumn{1}{|c|}{ Model } & Sum of Squares & Df & Mean Square & F & Sig. \\
\hline Regression & 86.926 & 2 & 43.463 & $\begin{array}{c}173.92 \\
4\end{array}$ & .000 \\
\hline Residual & 83.716 & 335 & .250 & & \\
\hline Total & 170.642 & 337 & & & \\
\hline
\end{tabular}

a. Predictors: (Constant), Customer and supplier relations, Product design

b. Dependent variable: organizational performance.

The multiple correlation coefficient $\mathrm{R}=0.714$ shows that there is a strong positive correlation between quality management capabilities (Customer and supplier relations and Product design) and organizational performance. It means that the dependent and independent variables turn in the same direction. The $\mathrm{R}$ value is a standard of how well the model portends the observed data. The value of $R^{2}=0.509$ shows that strategic flexibility can account for $50.9 \%$ of the variation of organizational performance. In addition, it means that the higher the quality management capabilities are, the better the applicability of organizational performance is to be expected.

The adjusted $R^{2}=0.506$ shows the generalizability of the model. It allows generalizing the results taken from the sample over the whole population. It is observed that the value of adjusted $R^{2}$ is very close to the value of $R^{2}$. If the adjusted $R^{2}$ is excluded from $R^{2}(0.509-0.506)$ then the result will be (0.003). This amount of decrease $(0.003)$ means that there will be $0.3 \%$ lower variance in the outcome if the whole population takes part in the study and that the model has been suited.

The second part of the output is the analysis of variance (ANOVA) which is used to statistically test the first main null hypotheses. It is concluded that the F-ratio for the data is173.924which is significant at $p<0.05$ (Alpha in this case equals sig=.000). This result shows that there is less than a $0.05 \%$ chance that an F-ratio of this value would only happen by chance. In conclusion, there is an effect of quality management capabilities (Customer and supplier relations and Product design) on organizational performance, and thus, we reject the null hypotheses.

The second part of multiple regression analysis is about testing the effect of the dependent variable in the model for each predictor. Standardized Beta coefficient $\beta$ and $\alpha$ significance levels were used to test the effect of quality management capabilities (Customer and supplier relations and Product design) on organizational performance.

Table 22. Coefficient of Predictors of the Third Main Hypothesis

\begin{tabular}{|c|c|c|c|c|c|}
\hline Model & \multicolumn{2}{|c|}{$\begin{array}{c}\text { Unstandardized } \\
\text { Coefficients }\end{array}$} & $\begin{array}{c}\text { Standardized } \\
\text { Coefficients }\end{array}$ & T & Tig. \\
\cline { 2 - 5 } & B & Std. Error & Beta & \\
\hline
\end{tabular}


Journal of Social Sciences (COES\&RJ-JSS), 8(3), pp.456-480

\begin{tabular}{|l|c|c|c|c|c|}
\hline (Constant) & .875 & .170 & & 5.155 & .000 \\
\hline $\begin{array}{l}\text { Customer and supplier } \\
\text { relations }\end{array}$ & .411 & .045 & .441 & 9.149 & .000 \\
\hline Product design & .344 & .047 & .354 & 7.359 & .000 \\
\hline
\end{tabular}

Dependent Variable: organizational performance

The standardized beta coefficient $(\beta)$ shows that the individual support of (mediating variable) predictors to the model, if other predictors are held fixed. Table 22 (above) shows the standardized coefficients for each quality management capabilities dimensions. First dimension is Customer and supplier relations, the $\beta$ coefficient was statistically significant where the significant level is .000 at $p>0.05$, while the other dimension which is product design was significant due to the significance level of $p=.000$ which is less than 0.05 , and this dimension has a strong effect on organizational performance where $\beta=0.344$.

Regarding the above testing of the third main hypothesis, the results of the third subhypotheses are described in the table 23 below.

Table 23. Results of Testing the Sub-Hypotheses of the Third Main Hypothesis

\begin{tabular}{|l|c|}
\hline \multicolumn{1}{|c|}{ Null Sub-hypotheses } & Result \\
\hline $\begin{array}{l}\text { H03.1: There is no effect of customer and supplier relations on } \\
\text { organizational performance. }\end{array}$ & Rejected \\
\hline H03.2: There is no effect of product design on organizational performance. & Rejected \\
\hline
\end{tabular}

The above table shows that the first sub-hypotheses was rejected due to the significance level $p>0.05$ which indicates that there is an effect of customer and supplier relations on organizational performance, likewise the second sub-hypotheses indicates that there is an effect of product design on organizational performance due to $p>0.05$.

\subsection{Testing the Fourth Hypothesis (Ho4)}

The fourth hypothesis states that there is no mediating role of quality management capabilities on the effect of information technology on organizational performance. Mediation is a hypothesized causal chain in which one variable affects a second variable that, in turn, affects a third variable. The intervening variable, $M$, is the mediator. It mediates the relationship between a predictor, X, and an outcome (Biesanz et al., 2010). Graphically, mediation can be depicted in the following way (Sekaran and Bougie, 2016):

$$
\mathrm{x} \quad-\mathrm{a} \rightarrow-\mathrm{b} \rightarrow
$$

Paths (a) and (b) are called direct effects, the meditational effect, in which $X$ leads to $Y$ through $M$, is called the indirect effect. The indirect effect represents the portion of the relationship between $X$ and $Y$ that is mediated by M (UPA, 2015).

In order to test for mediation Baron and Kenny (1986) proposed a four step approach in which several regression analyses are conducted and the significance of the coefficients is examined at each step. Table (24) presents a detailed explanation of the approach proposed by Baron and Kenny (1986).

Table 24. Steps for Testing Mediation

\begin{tabular}{|c|l|c|}
\hline & \multicolumn{1}{|c|}{ Analysis } & \multicolumn{1}{c|}{ Visual depiction } \\
\hline Step 1 & $\begin{array}{l}\text { Conduct a simple regression analysis with } \mathrm{X} \\
\text { predicting } \mathrm{Y} \text { to test for path c alone, } \mathrm{Y}=\mathrm{B}_{0}+\mathrm{B}_{1} \mathrm{X}+\mathrm{e}\end{array}$ & $\mathrm{C}$ \\
\cline { 2 - 3 }
\end{tabular}


The Effect of Information Technology on Organizational Performance:....

\begin{tabular}{|c|l|cc|}
\hline Step 2 & $\begin{array}{l}\text { Conduct a simple regression analysis with } \mathrm{X} \\
\text { predicting } \mathrm{M} \text { to test for path } \mathrm{a}, \mathrm{M}=\mathrm{B}_{0}+\mathrm{B}_{1} \mathrm{X}+\mathrm{e}\end{array}$ & $\mathrm{X}$ \\
\hline Step 3 & $\begin{array}{l}\text { Conduct a simple regression analysis with } \mathrm{M} \\
\text { predicting } \mathrm{Y} \text { to test the significance of path } \mathrm{b} \text { alone, } \mathrm{Y} \\
=\mathrm{B}_{0}+\mathrm{B}_{1} \mathrm{M}+\mathrm{e}\end{array}$ & $\mathrm{B}$ \\
\hline Step 4 & $\begin{array}{l}\text { Conduct a multiple regression analysis with } \mathrm{X} \text { and } \mathrm{M} \\
\text { predicting } \mathrm{Y}, \mathrm{Y}=\mathrm{B}_{0}+\mathrm{B}_{1} \mathrm{X}+\mathrm{B}_{2} \mathrm{M}+\mathrm{e}\end{array}$ & $\mathrm{C}$ \\
\hline
\end{tabular}

Steps 1-3 establish whether zero-order relationships among the variables exist. If one or more of these relationships are non-significant, researchers usually conclude that mediation is not possible or likely, however this may not always be true (MacKinnon et al., 2007). Assuming there are significant relationships from Steps 1 through 3, one proceeds to Step 4. In the Step 4 model, some form of mediation is supported if the effect of $M$ (path b) remains significant after controlling for $X$. If $X$ is no longer significant when $M$ is controlled, the finding supports full mediation. If $X$ is still significant (i.e., both $X$ and $M$ both significantly predict $Y$ ), the finding supports partial mediation (UPA, 2015). To test this hypothesis a combination of simple and multiple regression analyses were conducted as proposed by Baron and Kenny (1986). The results of the regression tests can be seen in table 25 . It is worth noting that the Baron and Kenny (1986) model of mediation focuses on the unstandardized regression coefficients, therefore, the coefficients mentioned in the below table represent the unstandardized betas.

Table 15. Regression Analysis for Mediation of Information Technology on Organizational Performance through Quality Management Capabilities

\begin{tabular}{|l|c|c|c|c|}
\hline & $\begin{array}{c}\text { Step 1: IT } \\
\text { and OP }\end{array}$ & $\begin{array}{c}\text { Step 2: IT and } \\
\text { QMC }\end{array}$ & $\begin{array}{c}\text { Step 3: QMC } \\
\text { and OP }\end{array}$ & $\begin{array}{c}\text { Step 4: IT, QMC } \\
\text { and OP }\end{array}$ \\
\hline Significance & 0.000 & 0.000 & 0.000 & 0.000 \\
\hline $\begin{array}{l}\text { Unstandardized } \\
\text { Beta for } \\
\text { Independent } \\
\text { Variable }\end{array}$ & 0.576 & 0.570 & & 0.253 \\
\hline $\begin{array}{l}\text { Unstandardized } \\
\text { Beta for } \\
\text { Mediating } \\
\text { Variable }\end{array}$ & 0.544 & 0.534 & 0.694 & 0.567 \\
\hline R & 0.296 & 0.285 & 0.489 & 0.530 \\
\hline$R^{2}$ & 0.294 & 0.283 & 0.488 & 0.527 \\
\hline Adj. R & 141.245 & 133.839 & 321.977 & 188.938 \\
\hline F-value & & & & \\
\hline
\end{tabular}

In order to determine whether quality management capabilities acts as a mediator in the effect of information technology in the organizational performance the following rule should be followed: some form of mediation is supported if the effect of the expected mediator remains significant after controlling for the independent variable. If the independent variable is no longer significant when the expected mediator is controlled, the finding supports full mediation. If the independent variable is still significant (i.e., both the independent variable and the expected mediator both significantly predict the dependent variable), the finding supports partial mediation (Baron and Kenny, 1986). Based on this rule, partial mediation 
exists since information technology and quality management capabilities both significantly predict organizational performance $(p$-values $=0.000)$. Furthermore, the strength of the independent variable in predicting the dependent should be reduced in the presence of the mediator variable in order to support partial mediation. In this case reject the null hypothesis since the three steps were significant and in the fourth step the independent variable remained significant but the unstandardized beta for information technology was reduced from 0.576 to 0.253 which supports the condition for partial mediation. According to Baron and Kenny (1986) having a partial mediation model is more realistic in most social science research because a single mediator cannot be expected to completely explain the relationship between the independent variable and the dependent variable.

\subsubsection{Discussion and Conclusion}

This study aims to investigating the effect of information technology in the organizational performance as mediated by quality management capabilities. Information technology dimensions' (electronic data interchange and enterprise resource planning). In addition, the quality management capabilities dimension (customer and supplier relations and product design). Organizational performance dimensions (customer satisfaction and customer responsiveness).

In this section, the main results of hypotheses testing will be discussed in order to address the research problem questions regarding the effect of information technology on the organizational performance as mediated by quality management capabilities. The result of statistical analysis shows a significant effect of information technology in the organizational performance through of quality management capabilities. Therefore, based on the study statistical results, the study found that there is a positive relationship between information technology (electronic data interchange and enterprise resource planning) and organizational performance in the pharmaceutical companies in Jordan. These results are consistent with (Chandler, 1998; Sanchez-Rodriguez and Martinez-Lorente, 2011; Rodríguez-Escobar and González-Benito, 2015; Mandal, 2015; Aldmour et al., 2017), the findings of this research endorse the idea that information technology is seen as empowerment tool to support and promote organizational performance for the firm's and financial outcomes. Additionally, the successful implementation of information technology in the pharmaceutical companies will improve and enhance the quality of company procedures; (such as, work efficiency, productivity and effectiveness). Additionally, the right adoption of information technology (electronic data interchange and enterprise resource planning) will improve the organization performance with regard to the financial status. Moreover, researchers have found that IT positively influences the organizational performance, in which the presence of EDI and ERP leads to more reliable and responsive behavior that boosts firm performance (Wai et al., 2011). Also, the study found that there is a positive relationship between information technology (electronic data interchange and enterprise resource planning) and quality management capabilities in the pharmaceutical companies in Jordan. These results are consistent with (Sanchez-Rodriguez and Martinez-Lorente, 2011; Rodríguez-Escobar and González-Benito, 2015). This indicates that the correct adoption of information technology (electronic data inter change and enterprise resource planning) will increase the degree of quality capabilities (customer supplier relations and product design) in taking the right decisions that might have a positive influence on organizational performance. Additionally using information technology in quality management capabilities may result in improving operational performance measures such as improves flexibility, faster delivery and improving costumer and supplier relationship (Rodríguez-Escobar and González-Benito, 2015).

This study found that there is a positive relationship between organizational performance and quality management capabilities (customer and supplier relations and product design). These 
results are consistent with (Malik et al., 2012; Patyal and Maddulety, 2015). This implies that pharmaceutical companies in Jordan consider their performance, whether it financial or operational as one of the most important priorities in their life cycle. Therefore, these results indicate that this type of companies highly focused on their customer satisfaction and customer responsiveness. Additionally quality management is a philosophy that focuses on customers at is faction and continuous improvement that enhances the organizational performance (Malik et al., 2012).

Finally, the study found quality management capabilities mediating the relationship between information technology and organizational performance. This indicates that the average variance explained in the presence of quality management capabilities is higher than in the absence of it. However, the study results found that quality management capabilities totally converted the directed relationship between information technology and organizational performance to indirect relationship and this indirect relationship became stronger when the quality management capabilities considered as a function of the information technology. This finding confirms that quality management capabilities is an integral mechanism that leverages and enhances the effect of information technology on organizational performance by improving quality of their products, and services through various quality management practices.

Based on the study results, we suggest the following recommendation that might be helpful to the pharmaceutical companies in Jordan with regard to the study concern. First, the findings of this research reflect a significant and positive effect of information technology on organizational performance as mediated by quality management capabilities; therefore; pharmaceutical companies should promote information technology for their work in order to respond to the changing customer requirements easily and quickly. Second, in light of the results showing that electronic data interchange has no effect on quality management capabilities, it is suggested to the firms to find the reasons that effect on this finding as electronic data interchange vary important dimension in information technology.Third, the study results show that enterprise resource planning, as a type of information technology, are very important due to its positive and significant effect on organizational performance. It is suggested to the firms to invest on it as much as possible, because of its ability to manage multiple areas of a firm including sales and purchases, production planning and scheduling, process design, inventory management, and quality control that leads to different benefits as an increase in productivity and a higher level of efficiency in the information flow. Finally, regards to the mediating effect of quality management capabilities in information technology effects on organizational performance, the findings of the study indicate that quality management capabilities does play a significant mediating role. Consequently, companies and managers should improve and enhance their quality capabilities by creating a creative culture that supports the concept of quality in their business, for its importance in focusing on customer satisfaction and continuous improvement that enhances the organizational performance.

However, several limitations should be noted in the study. One of the limitations is the sample size of 338 respondents which prevent the full representation of the market. Moreover, academic research and implications of quality management capabilities is in shortage in Jordan and Middle East. Therefore, the researchers are highly recommends the future researchers to focus on this variable. Since, this variable holds many benefits for organization future performance and societies. Third limitation, a quantitative approach used in the research methodology, for instance, conducting face-to-face interviews may provide better investigation tools and a different understanding of the effect of information technology in the organizational performance as mediated by quality management capabilities. Forth limitation, 


\section{Journal of Social Sciences (COES\&RJ-JSS), 8(3), pp.456-480}

this study only includes the pharmaceutical companies, so the results cannot be generalized upon other industries.

To conclude, a theoretical framework has been developed in this study to explore the effect of information technology in the organizational performance as mediated by quality management capabilities in Jordanian pharmaceutical companies. In addition, the analysis has answered a variety of the research questions. The findings have provided empirical support for the claim that information technology has a significant and positive effect on organizational performance through of quality management capabilities. Moreover, the results of the multiple regression analysis have showed that electronic data interchange has no effect on organizational performance, and that only enterprise resource planning and quality management capabilities consists of two dimensions (customer and supplier relations and product design) have a significant and positive effect on organizational performance.

\section{References}

Aldmour, R., Hammdan, F., Dmour, H., Alrowwad, A., and Khwaldeh, S. (2017). The Effect of Lifestyle on Online Purchasing Decision for Electronic Services: The Jordanian Flying E-Tickets Case. Asian Social Science, 13(11), 157-169.

Alenezi, H., Tarhini, A., and Masa'deh, R. (2015). Investigating the Strategic Relationship between Information Quality and E-Government Benefits: A Literature Review. International Review of Social Sciences and Humanities, 9(1), 33-50.

Alenezi, H., Tarhini, A., Alalwan, A., \& Al-Qirim, N. (2017). Factors Affecting the Adoption of EGovernment in Kuwait: A Qualitative Study. Electronic Journal of e-Government, 15(2), 84-102.

Allison, P. (1999). Multiple Regression: A Primer. Thousand Oaks, Pine Forge Press, CA.Analysis, (7th ed.). Pearson, Upper Saddle River, NJ.

Al-Shaikh, M.S., Torres, I.M., Zuniga, M.A., and Ghunaim, A. (2011). Jordanian Pharmaceutical Companies: Are their Marketing Efforts Paying off?. Health Marketing Quarterly, 28(2), 174189.

Altamony, H., Alshurideh, M., \& Obeidat, B. (2012). Information Systems for Competitive Advantage: Implementation of an Organizational Strategic Management Process. Proceedings of the 18th IBIMA Conference on Innovation and Sustainable Economic Competitive Advantage: From Regional Development to World Economic, Istanbul, Turkey, 9th-10th May.

Ang, C.L., Davies, M., and Finlay, P.N. (2000). Measures to Assess the Impact of Information Technology on Quality Management. International Journal of Quality \& Reliability Management, 17(1), 42-66.

Baron, R.M., and Kenny, D. (1986). The Moderator-Mediator Variable Distinction in Social Psychological Research: Conceptual, Strategic, and Statistical Considerations. Journal of Personality and Social Psychology, 51(6), 1173-1182.

Bhatt, G.D. (2001). Business Process Improvement through Electronic Data Interchange (EDI) Systems: An Empirical Study. Supply Chain Management: An International Journal, 6(2), 60-74. 
Biesanz, J.C., Falk, C.F., and Savalei, V. (2010). Assessing Mediational Models: Testing and Interval Estimation for Indirect Effects. Multivariate Behavioral Research, 45(4), 661-701.

Chandler, K. (1998). Quality in the Age of the Networked Society. Quality Progress, 31(1), 49.

Chavez, R., Yu, W., Jacobs, M.A., and Feng, M. (2017). Manufacturing Capability and Organizational Performance: The Role of Entrepreneurial Orientation. International Journal of Production Economics, 184, 33-46.

De Toni, A.F., Fornasier, A., and Nonino, F. (2015). The Impact of Implementation Process on the Perception of Enterprise Resource Planning Success. Business Process Management Journal, 21(2), 332-352.

Gay, L.R., and Airasian, P. (2000). Educational Research, (6th ed.). Columbus, OH: 169.

Hair, G. Black, B. Babin, B. Anderson, R. and Tatham, R. (2009). Multivariate Data Analysis, (7th ed.).

Hajli, M., Sims, J.M., and Ibragimov,V. (2015). Information Technology (IT) Productivity Paradox in the $21^{\text {st }}$ Century. International Journal of Productivity and Performance Management, 64(4), 457-478.

Jahanshahi, A. (2016). Disentangling the Emergence of Perceived Environmental Uncertainty among Technology Entrepreneurs. Kybernetes, 45(6), 962-976.

Kanaan, R., \& Masa'deh, R. (2018). Increasing Citizen Engagement and Participation through eGovernment in Jordan. Modern Applied Science, 12(11), 225-231.

Karajeh, H., \& Maqableh, M. (2014). Security of Cloud Computing Environment. The 23rd IBIMA Conference on Vision 2020: Sustainable Growth, Economic Development, and Global Competitiveness, USA, 2202-2215.

Khwaldeh, S., Al-Hadid, I., Masa'deh, R., \& Alrowwad, A. (2017). The Association between EServices Web Portals Information Quality and ICT Competence in the Jordanian Universities. Asian Social Science, 13(3), 156-169.

Kasiri, L.A., Cheng, K.T.G., Sambasivan, M., and Sidin, S.M. (2017). Integration of Standardization and Customization: Impact on Service Quality, Customer Satisfaction, and Loyalty. Journal of Retailing and Consumer Services, 35, 91-97.

Kelsey, P. (2015). Implementing EDIX12 Book Acquisitions at a Medium-Sized University Library. New Library World, 116(7/8), 383-396.

Lai, F., Zhao, X., and Wang, Q. (2006). The Impact of Information Technology on the Competitive Advantage of Logistics Firms in China. Industrial Management \& Data Systems, 106(9), 1249-1271.

Lakhal, L., Pasin, F., and Limam, M. (2006). Quality Management Practices and their Impact on Performance. International Journal of Quality \& Reliability Management, 23(6), 625-646. 
Li, D., Zhao, Y., Zhang, L., Chen, X., and Cao, C. (2018). Impact of Quality Management on Green Innovation. Journal of Cleaner Production, 170, 462-470.

MacKinnon, D.P., Fairchild, A.J. and Fritz, M.S. (2007). Mediation Analysis. Annual Review of Psychology, 58, 593-614.

Malik, A., Sinha, A., and Blumenfeld, S. (2012). Role of Quality Management Capabilities in Developing Market-based Organisational Learning Capabilities: Case Study Evidence from Four Indian Business Process Outsourcing Firms. Industrial Marketing Management, 41(4), 639-648.

Mandal, S. (2015). An Empirical-Relational Investigation on Supply Chain Responsiveness. International Journal of Logistics Systems and Management, 20(1), 59-82.

Middleton, K., Peh, W., Southern, S., Griffin, H., Sotlar, K., Nakahara, T., ...and Jenkins, D. (2003). Organization of Human Papillomavirus Productive Cycle during Neoplastic Progression provides a Basis for Selection of Diagnostic Markers. Journal of Virology, 77(19), 10186-10201.

Mjema, E.A.M., Victor, M.A.M., and Mwinuka, M.S.M. (2005). Analysis of Roles of IT on Quality Management. The TQM Magazine, 17(4), 364-374.

Narayanan, S., Narasimhan, R., and Schoenherr, T. (2015). Assessing the Contingent Effects of Collaboration on Agility Performance in Buyer-Supplier Relationships. Journal of Operations Management, 33, 140-154.

Nunnally, J. (1978). Psychometric Theory (2nd ed.), McGraw-Hill, NY.

Oly Ndubisi, N., Kok Wah, C., and Ndubisi, G.C. (2007). Supplier-Customer Relationship Management and Customer Loyalty: The Banking Industry Perspective. Journal of Enterprise Information Management, 20(2), 222-236.

Patyal, V.S., and Maddulety, K. (2015). Interrelationship between Total Quality Management and Six Sigma: A Review. Global Business Review, 16(6), 1025-1060.

Pehrsson, A. (2014). Firms' Customer Responsiveness and Performance: The Moderating Roles of Dyadic Competition and Firm's Age. Journal of Business \& Industrial Marketing, 29(1), 34-44.

Power, D. (2014). Competence and Capability in Quality in the High-tech Sector: An International Comparison. International Journal of Operations \& Production Management, 34(9), 1184-1209.

Rodríguez-Escobar, J.A., and González-Benito, J. (2015). The Role of Information Technology in Purchasing Function. Journal of Business \& Industrial Marketing, 30(5), 498-510.

Sanchez-Rodriguez, C., and Rafael Martinez-Lorente, A. (2011). Effect of IT and Quality Management on Performance. Industrial Management \& Data Systems, 111(6), 830-848.

Sekaran, U., and Bougie, R.J. (2016). Research Methods for Business: A Skill Building Approach (7th ed). John Wiley \& Sons. 
Shatat, S., and Udin, M. (2012). The Relationship between ERP System and Supply Chain Management Performance in Malaysian Manufacturing Companies. Journal of Enterprise Information Management, 25(6), 576-604.

Tabachnick, B., and Fidell, L. (2007). Using Multivariate Statistics, (6th ed.), Boston: Allyn and Bacon.

Tan, K., Kannan,V.R., Hsu, C.C., and Leong, G. (2010). Supply Chain Information and Relational Alignments: Mediators of EDI on Firm Performance. International Journal of Physical Distribution \& Logistics Management, 40(5), 377-394.

Tarhini, A., Al-Badi, A., Almajali, M., \& Alrabayaah, S. (2017a). Factors Influencing Employees' Intention to Use Cloud Computing. Journal of Management and Strategy, 8(2), 47.

Tarhini, A., Al-Busaidi, K., Bany Mohammed, A., \& Maqableh, M. (2017b). Factors Influencing Students' Adoption of E-Learning: A Structural Equation Modeling Approach. Journal of International Education in Business, 10(2), 164-182.

Tarhini, A., Mgbemena, C., \& Trab, MSA. (2015). User Adoption of Online Banking in Nigeria: A Qualitative Study. Journal of Internet Banking and Commerce, 20(3), 1-8.

Tseng, S.M., and Wu, P.H. (2014). The Impact of Customer Knowledge and Customer Relationship Management on Service Quality. International Journal of Quality and Service Sciences, 6(1), 77-96.

UPA (2015). Testing Mediation with Regression Analysis. Available from: http://www.upa.pdx.edu/IOA/newsom/da2/ho_mediation.pdf [Accessed December 2015].

Wai, L., Seebaluck, A., and Teeroovengadum, V. (2011). Impact of Information Technology on Quality Management Dimensions and its Implications. European Business Review, 23(6), 592608.

Williams, B., Brown, T., and Onsman, A. (2010). Exploratory Factor Analysis: A Five-Step Guide for Novices. Australasian Journal of Paramedicine, 8(3), 1-13.

Winniford, M., Conger, S., and Erickson-Harris, L. (2009). Confusion in the Ranks: IT Service Management Practice and Terminology. Information Systems Management, 26(2), 153-163.

Xia, Y., Singhal, V.R., and Zhang, G. (2015). Product Design Awards and the Market Value of the Firm. Production and Operations Management, 25(6), 1038-1055.

Yassien, E., \& Mufleh, M. (2017). The Impact of ERP System's Usability on Enterprise Resource Planning Project Implementation Success via the Mediating Role of User Satisfaction. Journal of Management Research, 9(3), 49-71. 